\title{
Study of knowledge of caretakers with children suffering from sickle cell anaemia regarding disease and prevention of transmission
}

\author{
Asruti Kacha ${ }^{*}$, Anand Shah ${ }^{2}$, Sheila Aiyer ${ }^{3}$ \\ ${ }^{1,2}$ Assistant Professor, ${ }^{3}$ Additional Professor, ${ }^{1,3}$ Dept. of Paediatric, ${ }^{2}$ Dept. of Community and Oncology, ${ }^{1,3}$ Government Medical College, \\ Vadodara, Gujarat, ${ }^{2}$ The Gujarat Cancer \& Research Institute, Ahmedabad, Gujarat, India
}

*Corresponding Author: Asruti Kacha

Email: asrutikacha11111@gmail.com

\begin{abstract}
Introduction: Sickle Cell Anaemia (SCA) is a haemoglobinopathy that affects millions throughout the world. It leads to poor quality of the life and increased mortality in children and young adults

Objectives: The objective of the study is to assess knowledge of caretakers with children suffering from sickle cell anaemia regarding disease and prevention of transmission.

Materials and Methods: This prospective study includes total 103 participants. All the patients with SCA admitted in paediatric ward fulfilling all the inclusion and exclusion criteria were referred to paediatric haematology clinic and their caretakers were interviewed there. Data were collected via a pre-tested, structured questionnaire filled in by a Research assistant who interviewed caretakers after obtaining both oral and written informed consent. Caretakers were interviewed about their knowledge regarding SCA, care of their SCA children and prevention of transmission. Necessary socio-demographic characteristics of the children and their caretakers were collected.

Results: A total of 103 caretakers were enrolled into the study. Among them, $46 \%(n=47)$ had age between $26-30$ years and majority of them were Hindu $85.4 \%(n=88)$ and from rural $84.5 \%(n=87)$, locality. $69.9 \%$ of caretakers had education less than or equal to 8 std.20.4\% caretakers knew that SCA is an inherited blood disorder.14.6\% were aware of carrier state of SCA. Amongst the various symptoms of sickle cell anaemia, most of the care takers had knowledge of joint pain $83 \%(n=86)$ and pallor $75 \%$ ( $n=78$ ), followed by recurrent jaundice $45 \%(n=46) .58 .25 \%(n=60)$ knew, it is diagnosed by blood test. Majority of respondents $81.55 \%(n=84)$ knew their child should drink 10 15 glasses of water per day. Majority $78.64 \%(\mathrm{n}=81)$ of them knew about importance of daily folic acid tablets.18.4\% caretakers knew that sickle cell anaemia is preventable and $28.15 \%$ had knowledge about pre-marital screening of spouse of their diseased child. Caretakers who had other SCA affected child had better knowledge of the symptoms of disease than caretakers who had only single diseased child.

Conclusion: From this study it is concluded that more efforts need to be done to promote sickle cell awareness in Gujarat tribal communities with emphasis on health education campaigns and counselling of high risk population.
\end{abstract}

Keywords: Knowledge, Caretaker, Sickle cell anaemia.

\section{Introduction}

Sickle Cell Anaemia (SCA) is the most common monogenic blood disorder worldwide. SCA is autosomal recessive, hereditary anaemia responsible for considerable morbidity and mortality. ${ }^{1,2}$ SCA occurs due to inherited abnormal haemoglobin gene, which produce Haemoglobin S ( HbS). $\mathrm{HbS}$ is the result of a single base pair change, thymine for adenine, at the $6^{\text {th }}$ codon of the b-globin gene. This change encodes valine instead of glutamine in the $6^{\text {th }}$ position in $b$ globin molecule. Sickle cell anaemia, homozygous HbS, occurs when both b-globin genes have the sickle cell mutation. ${ }^{3}$

According to WHO, about $5 \%$ of world's population carries the gene responsible for haemoglobin disorders. About 3lacs children are born worldwide with SCA every year. ${ }^{5}$ India has also very huge population of tribal community, about 18 crores and expected to have 1.80 crores sickle cell trait and 14lacks of sickle cell anaemia. This shows the big burden on public health. They have high prevelance of socio-economic disadvantage and are frequently medically underserved. In India, Gujarat, Maharashtra, Chhattisgarh, Madhya Pradesh, Orissa, Andhra Pradesh and Tamilnadu have problem of SCA in tribal areas in variable quantum. ${ }^{6}$

Gujarat has 8.912 million tribal population and is expected to have at least 9,00,000 sickle cell trait and
70,000 sicke cell anaemia patients. According to ICMR survey, amongst the primitive tribes of south of Gujarat, $30 \%$ of sickle cell disease children die before 14 years and remaining $70 \%$ die by the age of 50 years. ${ }^{6}$

The high incidence of SCA in tribals of Gujarat makes it a public health problem. In Gujarat, children with sickle cell anemia are usually first diagnosed following an acute illness and not by screening. Tribal districts of Gujarat are Dang, Valsad, Tapi, Surat, Banaskantha, Sabarkantha, Godhara, Dahod and Narmada. Our S.S.G. Hospital, Vadodara is being in centre to these districts. Most of the patients from above districts are referred to S.S.G. Hospita, Vadodara for crisis management.

If care takers of children suffering from SCA, have adequate knowledge of etiology, symptoms and crisis, they can develop necessary practices to care for their children. SCA is a preventable health problem that is commonly occurring in couples who are not aware of their genotypes. There is a persistant need to focus on primary prevention of SCA through public health education and other control measures. Decent knowledge about SCA is needed for individuals especially carriers to make informed decisions about their reproductive life and other health related choices. 
The objective of the study is to assess knowledge of caretakers with children suffering from sickle cell anaemia regarding disease and prevention of transmission.

\section{Materials and Methods}

This prospective cross sectional study was conducted at Paediatric department, Government medical college, SSG hospital, Vadodara, Gujarat from April 2018 to February 2019. Study includes 103 caretakers of children with SCA who were diagnosed as SCA at least 3 months back from the date of interview. Caretakers of children with double heterozygous of sickle-thalassemia, other hemoglobinopathies and caretakers with only sickle trait children were not included.

All the patients with SCA admitted in paediatric ward fulfilling all the inclusion and exclusion criteria were referred to paediatric haematology clinic and their caretakers were interviewed there. Caretakers of children who were already diagnosed outside SSG hospital and referred to SSG hospital were also included. Explanation on objective of study and relevance of study was given before the interview to each respondent. Confidentiality was maintained about the patient's details included in study.

Data were collected via a pre-tested, structured questionnaire filled in by a research assistant who interviewed caretakers after obtaining both oral and written informed consent from each respondent. Information regarding socio-demographic characteristics like age, gender, marital status, and knowledge, attitude and practices regarding sickle cell disease was recorded in a pre-designed and pre-tested proforma.

Caretakers were interviewed about their knowledge regarding etiology, symptoms, care of their SCA children and prevention of transmission. Necessary sociodemographic characteristics of the children and their caretakers were also collected

\section{Data Analysis}

The data were entered by using MS Office Excel in a password protected file.

Data analysis was done by using Med $\mathrm{CalC}$ version 12.5.0.0. (Trial version). Data were analysed for sociodemographic characteristics of children and their caretakers using descriptive statistics. Care takers knowledge regarding etiology, symptoms, care of their children, screening and prevention of transmission were analysed using frequency table. Categorical variables were subjected to Chi-square test.

\section{Results}

Study includes total 103 participants. Among them 66\% $(n=68)$ male and $34 \%(n=35)$ were female caretakers.

Demographic characteristics of the caretakers based on age, gender, religion, locality, education, monthly income etc. are mentioned in Table 1.

Table 1 shows that $66 \%(n=68)$ male and $34 \%(n=35)$ were female caretakers.
Majority of caretakers $46 \% \quad(n=47)$ were having age between 26-30 years and majority of them were Hindu $(\mathrm{n}=88,85.4 \%)$ and from rural $(\mathrm{n}=87,84.5 \%)$ locality.

$69.9 \%$ of caretaker had education less than or equal to 8 standard and $30.1 \%$ of them had education more than 8 standard.

$20.4 \%$ caretakers knew that SCA is an inherited blood disorder while $79.6 \%$ didn't know about inherited nature of disease. Only $14.6 \%(n=15)$ were aware of carrier state of SCA.

Table 2 shows that among the various symptoms of sickle cell disease, most of the care takers have knowledge of joint pain $86(83 \%)$ and pallor $78(75 \%)$ followed Recurrent jaundice 46(45\%).60(58.25\%) know it is diagnosed by blood test, while 43(41.74\%) do not know about its diagnosis.

Majority of respondents $81.55 \%$ (84) knew their child should drink 10-15 glasses of water per day and only $54.36 \%$ (56) respondents knew about avoidance of high altitude by their children. Majority $78.64 \%$ (81) of them knew about importance of daily folic acid tablets.

$78.6 \%(n=81)$ study subjects agreed that there is need to take regularly treatment for their SCA child. Majority $82.52 \%(\mathrm{n}=85)$ caretakers were aware about availability of free treatment for SCA at government health facilities, while $17.47 \%(n=18)$ didn't know about availability of free of cost treatment.

$61.16 \%$ (63) caretakers knew that family members of diseased child should be screened for the same.

$21.36 \%$ respondents had sickle cell trait and $7.76 \%$ had sickle cell anaemia. 3.88\% respondents knew that they had sickle but didn't know the difference between sickle tait and disease. $13.59 \%$ respondents had false belief that they don't have sickle tait or disease.

$18.4 \%(n=19)$ caretakers knew that sickle cell anaemia is preventable and $81.5 \%(n=84)$ believed that it is not preventable.

$67 \%(\mathrm{n}=69)$ knew that their other children also need testing of sickle cell anaemia.

$28.15 \%$ caretakers had knowledge about pre-marital screening of spouse of their diseased child and $21.35 \%$ had knowledge about pre-marital screening of spouse of their other children.

Table 7 shows that Caretakers who had other SCA affected child had better knowledge of the symptoms of disease than caretakers who had only single diseased child. $P$ value among them also found significant. 
Table 1: Demographic characteristics of the participants $(n=103)$

\begin{tabular}{|l|c|c|c|}
\hline Variable & Sub variable & Numbers & Percentage (\%) \\
\hline \multirow{4}{*}{ Age } & $\leq 20$ years & 1 & 0.97 \\
\cline { 2 - 4 } & $21-25$ years & 25 & 24.2 \\
\cline { 2 - 4 } & $26-30$ years & 47 & 45.63 \\
\cline { 2 - 4 } & $31-35$ years & 23 & 22.33 \\
\cline { 2 - 4 } & Above 35 years & 7 & 6.79 \\
\cline { 2 - 4 } Gender of care taker & Male & 68 & 66.0 \\
\hline \multirow{3}{*}{ Religion } & Female & 35 & 34.0 \\
\cline { 2 - 4 } & Hindu & 88 & 85.4 \\
\cline { 2 - 4 } & Muslim & 13 & 12.6 \\
\hline \multirow{2}{*}{ Locality } & Christian & 2 & 1.9 \\
\hline \multirow{2}{*}{ Education } & Urban & 16 & 15.5 \\
\cline { 2 - 4 } & Rural & 87 & 84.5 \\
\cline { 2 - 4 } & $\geq 8$ Standard & 31 & 30.1 \\
\cline { 2 - 4 } & $<8$ standard & 72 & 18.9 \\
\cline { 2 - 4 } & 5000 & 36 & 35.0 \\
\cline { 2 - 4 } & 5001 to 10000 & 48 & 46.6 \\
\hline
\end{tabular}

Table 2: Knowledge of caretakers regarding symptoms of sickle cell anaemia

\begin{tabular}{|l|c|c|c|}
\hline Knowledge of Symptoms & Yes & No & Don't Know \\
\hline Pallor & $78(75.72 \%)$ & $3(2.91 \%)$ & $22(21.36 \%)$ \\
\hline Splenomegaly & $44(42.71 \%)$ & $12(11.65 \%)$ & $47(45.63 \%)$ \\
\hline Joint Pain & $86(83.49 \%)$ & $5(4.85 \%)$ & $12(11.65 \%)$ \\
\hline Recurrent Jaundice & $46(44.66 \%)$ & $23(22.33 \%)$ & $34(33.00 \%)$ \\
\hline Recurrent Infection & $45(43.68 \%)$ & $10(9.70 \%)$ & $48(46.60 \%)$ \\
\hline
\end{tabular}

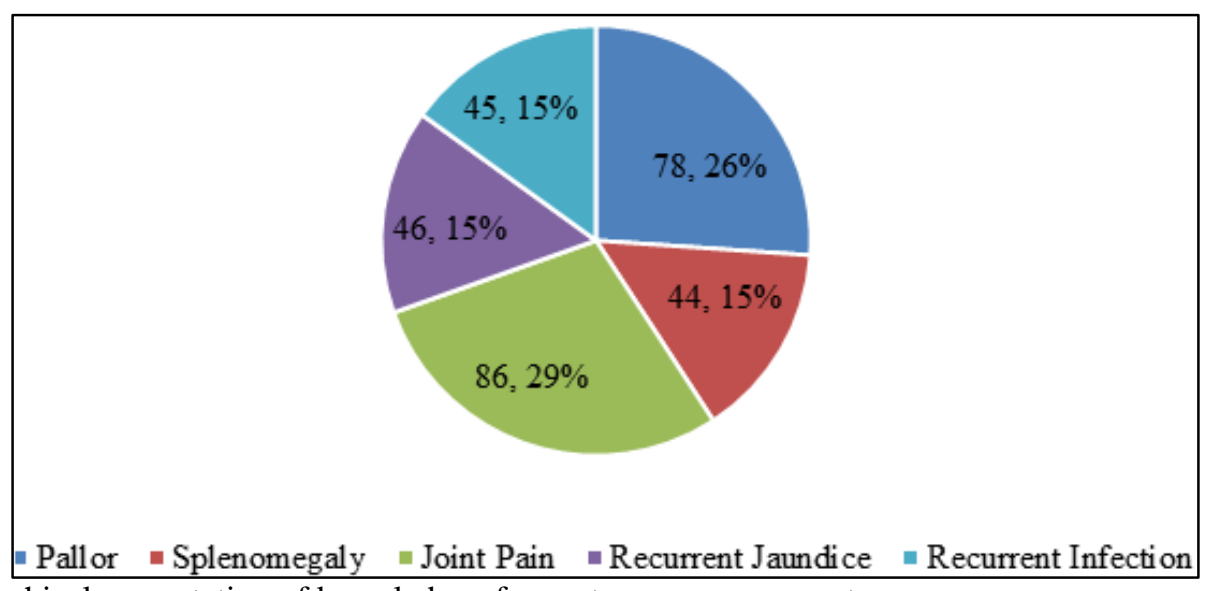

Fig. 1: Showing graphical presentation of knowledge of symptoms among parents

Table 3: knowledge regarding precautions to be taken to live healthy life

\begin{tabular}{|l|c|c|c|}
\hline Variable & Yes (\%) & No (\%) & Don't Know (\%) \\
\hline Drink 10-15 glass water/day & $84(81.55 \%)$ & $1(0.97 \%)$ & $18(17.47 \%)$ \\
\hline Avoid straineous activity & $66(64.07 \%)$ & $8(7.76 \%)$ & $29(28.15 \%)$ \\
\hline Winter care & $75(72.81 \%)$ & $2(1.94 \%)$ & $26(25.24 \%)$ \\
\hline Summer care & $70(67.96 \%)$ & $7(6.79 \%)$ & $26(25.24 \%)$ \\
\hline Avoid drenching in rain & $70(67.96 \%)$ & $7(6.79 \%)$ & $26(25.24 \%)$ \\
\hline Avoid going to high altitude & $56(54.36 \%)$ & $4(3.88 \%)$ & $43(41.74 \%)$ \\
\hline Regular folic acid & $81(78.64 \%)$ & - & $22(21.35 \%)$ \\
\hline
\end{tabular}


Table: 4: Knowledge of caretakers for requirement of screening

\begin{tabular}{|l|c|c|c|}
\hline & Yes & No & Don't Know \\
\hline Symptomatic & $59(57.28 \%)$ & $4(3.88 \%)$ & $40(38.83 \%)$ \\
\hline Family members of Diseased & $63(61.16 \%)$ & $1(0.97 \%)$ & $39(37.86 \%)$ \\
\hline All Tribes & $40(38.83 \%)$ & $1(0.97 \%)$ & $62(60.19 \%)$ \\
\hline
\end{tabular}

Table 5: Knowledge of own and spouse sickle status

\begin{tabular}{|l|c|c|c|c|c|}
\hline & Don't Know & Sickle trait & Sickle Disease & Sickle & No Disease or Trait \\
\hline Own status & $55(53.39 \%)$ & $22(21.36 \%)$ & $8(7.76 \%)$ & $4(3.88 \%)$ & $14(13.59 \%)$ \\
\hline Spouse Status & $54(52.42 \%)$ & $16(15.53 \%)$ & $8(7.76 \%)$ & $17(16.50 \%)$ & $8(7.76 \%)$ \\
\hline
\end{tabular}

Table 6: knowledge regarding Need for Pre- Marital Screening of spouse of their child

\begin{tabular}{|l|c|c|c|}
\hline & Yes & No & Don't Know \\
\hline Spouse of disease child & $29(28.15 \%)$ & $12(11.65 \%)$ & $62(60.19 \%)$ \\
\hline Spouse of other children & $22(21.35 \%)$ & $10(9.70 \%)$ & $71(68.93 \%)$ \\
\hline
\end{tabular}

Table7: Correlation between more than one SCD children and knowledge of symptoms

\begin{tabular}{|c|c|c|c|c|c|}
\hline \multicolumn{2}{|c|}{ Having other sibling with SCD } & \multirow{2}{*}{$\begin{array}{c}\begin{array}{c}\text { No. } \\
\text { Frequency (\%) }\end{array} \\
17(42.5 \%) \\
\end{array}$} & \multirow{2}{*}{$\begin{array}{c}\text { Yes } \\
\text { Frequency }(\%) \\
5(7.9 \%)\end{array}$} & \multirow{2}{*}{$\begin{array}{c}\text { p value } \\
0.002\end{array}$} & \multirow{2}{*}{$\begin{array}{c}\text { Chi-square } \\
17.4\end{array}$} \\
\hline Pallor & DK & & & & \\
\hline & $\mathrm{N}$ & $1(2.5 \%)$ & $2(3.2 \%)$ & & \\
\hline & $\mathrm{Y}$ & $22(55.0 \%)$ & $56(88.9 \%)$ & & \\
\hline \multirow[t]{3}{*}{ Splenomegaly } & DK & $30(75.0 \%)$ & $16(25.4 \%)$ & \multirow[t]{3}{*}{0.01} & \multirow[t]{3}{*}{24.3} \\
\hline & $\mathrm{N}$ & $2(5.0 \%)$ & $10(15.9 \%)$ & & \\
\hline & $\mathrm{Y}$ & $8(20.0 \%)$ & $37(58.7 \%)$ & & \\
\hline \multirow[t]{3}{*}{ Joint pain } & DK & $11(27.5 \%)$ & $1(1.6 \%)$ & \multirow[t]{3}{*}{0.003} & \multirow[t]{3}{*}{16.1} \\
\hline & $\mathrm{N}$ & $2(5.0 \%)$ & $3(4.8 \%)$ & & \\
\hline & $\mathrm{Y}$ & $27(67.5 \%)$ & $59(93.7 \%)$ & & \\
\hline \multirow[t]{3}{*}{ Recurrent jaundice } & DK & $24(60.0 \%)$ & $9(14.3 \%)$ & \multirow[t]{3}{*}{0.001} & \multirow[t]{3}{*}{20.37} \\
\hline & $\mathrm{N}$ & $5(12.5 \%)$ & $18(28.6 \%)$ & & \\
\hline & $\mathrm{Y}$ & $5(12.5 \%)$ & $18(28.6 \%)$ & & \\
\hline \multirow[t]{3}{*}{ Recurrent infection } & DK & $11(27.5 \%)$ & $36(57.1 \%)$ & \multirow[t]{3}{*}{0.001} & \multirow[t]{3}{*}{20.651} \\
\hline & $\mathrm{N}$ & $29(72.5 \%)$ & $17(27.0 \%)$ & & \\
\hline & $\mathrm{Y}$ & $4(10.0 \%)$ & $19(30.2 \%)$ & & \\
\hline
\end{tabular}

(DK-don't know, Y:yes, N:no) (p value less than 0.05 -significant)

\section{Discussion}

During 2005-06, a comprehensive sickle cell programme based on public-private partnership was started and now it has been extended to all 12 tribal districts of Gujarat from 2008. Under this programme, newborn screening, mass screening of adolescents and antenatal mothers are done in tribal areas. Marriage counselling and genetic counselling are done to prevent transfer into next generation. Testing of disease and supportive treatment are given to free of cost to all. This study is an endeavour to assess knowledge of caretakers with sickle cell anaemia child.

In the present study, $24.4 \%$ study subjects had knowledge regarding the hereditary nature of the disease. $61.16 \%$ (63) caretakers knew that family members of diseased child should be screened for the same $21.36 \%$ respondents had sickle cell trait and $7.76 \%$ had sickle cell anaemia. $3.88 \%$ respondents knew that they had sickle but didn't know the difference between sickle tait and disease. $13.59 \%$ respondents had false belief that they don't have sickle tait or disease.18.4\% $(\mathrm{n}=19)$ caretakers knew that sickle cell anaemia is preventable and $81.5 \% \quad(n=84)$ believed that it is not preventable. 67\% $(n=69)$ knew that their other children also need testing of sickle cell anaemia Gamit et al, found only $9 \%$ study subjects knew the hereditary nature of SCA whereas Patil SS et al, reported $62.5 \%$, Coretta et al reported $45 \%$ and Kofi et al observed that $75 \%$ patients knew the hereditary nature of the disease. ${ }^{7-10}$

In this study, $78.64 \%(n=81)$ study subjects knew that folic acid should be taken regularly for SCA. Patil SS et al, Coretta $\mathrm{M}$ et al and Treadwell $\mathrm{M}$ et al, reported lower proportion of knowledge compared to present study. ${ }^{8,9,11}$

In the present study $78.64 \%$ study subjects agreed that there is need to take regularly treatment for sickle cell anaemia. Similar findings were reported by Olatano et al, Coretta et al and Kofi et al. ${ }^{12,9,10}$

In the present study, $29.12 \% \quad(n=30)$ study subjects were aware about own sickle cell status and $23.3 \%(n=24)$ were aware about sickle cell status of their spouse. In the study conducted by Patil SS et al $68.34 \%$ study subjects 
knew sickle cell status of their family members. In present study, lower proportion of study subjects were aware about sickle cell status of their spouse. ${ }^{8}$

Amongst the study subjects, about $19.41 \%$ agreed that there is need for pre-marietal screening of spouse for SCA. Similar findings were noted by Patil SS et al, Gamit C et al, Treadwell et a, Abd Nazir et al. Knowledge towards premarietal screening of spouse for SCA was not good $8,7,11,13$

Majority of study subjects, $67 \%$ agreed that all children should be screened for SCA. The study reviewed that participants who had more than one child with sickle cell anaemia and a family history of sickle cell had good knowledge about the disease symptoms.

This is similar to a study that was done by Acharya and colleagues in 2009 that reviewed that among parents with child identified with sickle cell disease or trait and parents known to have either trait or disease, the level of knowledge about sickle cell was good, ${ }^{14}$ furthermore; Treadwell and colleagues established that respondents who learnt information from friends and family were three times more likely to know their trait status, demonstrating potential benefit of family discussions about sickle cell. ${ }^{11}$

\section{Conclusion}

This study shows that knowledge regarding symptoms, precautions to be taken to live healthy life, treatment of SCA is satisfactory in caretakers with diseased child. But knowledge related to cause, carrier status, need of screening and prevention of SCA is infrequent. Because if which it is difficult to combat against this preventable disease.

Actually there is no similar study in Gujarat, Therefore, this study outcome is more useful for the management of sickle cell anaemia control programme. This study recommends to plan effective strategies to intensify health education of community in sickle cell anaemia control programme through mass campaigns, personal counselling, traditional media, audio-visual aids etc. In today's era of digitalization, internet and social media can be used effectively. Mass screening programme provides an ideal opportunity.

\section{Acknowledgements}

We acknowledge all the participants for their participation and contribution. We sincerely thank all those who were directly or indirectly involved in the study.

\section{Source of funding}

None.

\section{Conflict of interest}

None.

\section{Ethical approval}

The study was done after permission of institutional Ethics committee.

\section{References}

1. Kamble M, Chaturvedi P. Epidemiology of sickle cell disease in rural hospital of central India. Indian Paediatr $J$ 2000;37(4):391-6.

2. Harrison T. Hemoglobinopathies, hematopoetic disorders. In: Harrisons principles if Internal Medicine. $18^{\text {th }}$ edition. McGraw-Hill Publishers; 2011:593-600.

3. Nathan, Oski's. Hematology of Infancy and Childhood, $7^{\text {th }}$ ed.ch 19, sickle cell disease, page no:948.

4. Nelson. Textbook of Pediatrics, $18^{\text {th }}$ ed.chat 462.1 , sickle cell disease, page no:2026-30.

5. World Heaith Organization. $59^{\text {th }}$ World Health Assembly. Provisional agenda, item no. 11.4. Sickle Cell Anemia: Report by secretariant 2006, WHO, 2006.

6. Sickle cell anemia programme manual, epidemic branch, Gujrat.

7. Gamit C, Kantharia S, Patni M, Parmar G, Kaptan K. A study of knowledge, attitude and practice about sickle cell anaemia in patients with positive sickle cell status in bardolitaluka. Int $J$ Med Sci Public Health 2014;3(3):365-8.

8. S. S. Patil, A. A. Thikare, S. K. Wadhva, Knowledge attitude and practice regarding sickle cell disease in adult sufferers and carriers in rural area; Int J Community Med Public Health 2017;4(4):1075 -80.

9. Coretta M, Brewer C, Jenerette N. Health-Related Stigma in Adults with Sickle Cell Disease. J National Med Assoc. 2010;102(11):1050-5.

10. Kofi A, Egunjobi F, AkinyanjuO. Psychosocial impact of sickle cell disorder: perspectives from a Nigerian setting. Glob Health 2010;6(2):101-7.

11. Threadwell M.J, McClough L. Using qualitative and quantitative strategies to evaluate knowledge and perceptions about sickle cell disease and sickle cell trait. J Natl Med Assoc 2006;98(5):704-10.

12. Olatona A, Odeyemi A, Onajole T, Asuzu M. Effects of heaith education on knowledge and attitude of youth corps members to sickle cell disease and its screening in Lagos state. $J$ Community Med Health 2012;2(7):251-7.

13. Al Nasir FA, Niazi G. Sickle cell disease: Patients' awareness and management. Annals Saudi Med 1998:18(1):63-5.

14. Acharya K, Lang CW, Ross LF A pilot study to explore knowledge, attitudes, and beliefs about sickle cell trait and disease. J Natl Med Assoc 2009;101:1163-72.

How to cite this article: Kacha A, Shah A, Aiyer S. Study of Knowledge of caretakers with children suffering from sickle cell anaemia regarding disease and prevention of transmission. Int J Med Paediatr Oncol 2019;5(4):112-6. 